IZA DP No. 6129

Disparities in Social Assistance Receipt between Immigrants and Natives in Sweden

Björn Gustafsson

November 2011 


\title{
Disparities in Social Assistance Receipt between Immigrants and Natives in Sweden
}

\author{
Björn Gustafsson \\ University of Gothenburg \\ and IZA
}

\section{Discussion Paper No. 6129 \\ November 2011}

\author{
IZA \\ P.O. Box 7240 \\ 53072 Bonn \\ Germany \\ Phone: +49-228-3894-0 \\ Fax: +49-228-3894-180 \\ E-mail: iza@iza.org
}

\begin{abstract}
Any opinions expressed here are those of the author(s) and not those of IZA. Research published in this series may include views on policy, but the institute itself takes no institutional policy positions.

The Institute for the Study of Labor (IZA) in Bonn is a local and virtual international research center and a place of communication between science, politics and business. IZA is an independent nonprofit organization supported by Deutsche Post Foundation. The center is associated with the University of Bonn and offers a stimulating research environment through its international network, workshops and conferences, data service, project support, research visits and doctoral program. IZA engages in (i) original and internationally competitive research in all fields of labor economics, (ii) development of policy concepts, and (iii) dissemination of research results and concepts to the interested public.
\end{abstract}

IZA Discussion Papers often represent preliminary work and are circulated to encourage discussion. Citation of such a paper should account for its provisional character. A revised version may be available directly from the author. 
IZA Discussion Paper No. 6129

November 2011

\section{ABSTRACT \\ Disparities in Social Assistance Receipt between Immigrants and Natives in Sweden}

Social assistance receipt among immigrants in relation to receipt among natives in Sweden is investigated. A background of how the system is constructed is provided, statistical information reported, the literature surveyed and key results interpreted. Most out-payment for social assistance in Sweden refers to foreign born persons although the category makes up 14 percent of the population. While some part of the high costs can be attributed to needs to maintaining recent refugees, this is not the entire story. Immigrants tend to assimilate out of social assistance receipt. However, receipt continues to be higher than among in several characteristics identical natives many years after immigration among immigrants from not rich countries. The elevated probabilities of social assistance receipt among immigrants from not rich countries are mainly due to failures of integrating into the labor market at the destination.

JEL Classification: F22, I38, J15

Keywords: $\quad$ social assistance, immigrants, Sweden

Corresponding author:

Björn Gustafsson

Department of Social Work

University of Gothenburg

P.O. Box 720

40530 Göteborg

Sweden

E-mail: Bjorn.Gustafsson@socwork.gu.se 


\section{Introduction}

The Swedish social welfare system is by many perceived as having a number of attractive characteristics. Thus in international comparisons Sweden is often found in the group of countries having the lowest incidence of financial poverty, see for example OECD (2008). Major reasons for such a favorable state are comparatively high labor force participation of men as well as by women and the existence of a relatively generous income safety net. However, the access to and the generosity of social insurance payments depend on household members qualifying by working for pay. Recently arrived immigrants as well as young adults have typically not qualified to for example unemployment compensation and are therefore more likely than others to turn to social assistance: the last income safety-net.

During the 50, 60 and first half of the 70s did most foreign born arrive as work migrant or as their relatives. They originating with few exceptions from European countries and most became well integrated into the Swedish labor market. The proportion of refugees and their family members has been much larger in the immigrant streams that arrived during the 80s and thereafter. The origin has also changed towards a larger proportion of people from middle and low income countries. Many of those "new" immigrants differ substantially from the majority population by appearance and name. The fact that many immigrants who arrived during the 80s and thereafter are not well integrated into the Swedish labor market is widely acknowledged and subject to much concern.

The seriousness of the issue shows up in that a minority rich countries now-days face a larger employment gap between foreign born and native born than Sweden. (OECD, 2009) This must also be deemed as the major reason why a much larger proportion of foreign born than native born receive social assistance. Foreign born also on average have longer periods of social assistance receipt than natives. Higher rates of receipt and longer duration lead to that since some years most public expenditures for social assistance in contemporary Sweden are the out payments to foreign born recipients.

The task for this paper is to provide an overview of the issue of social assistance receipt among immigrants to Sweden and put it in relation to receipt by natives. It is based on knowledge of relevant institutions, published statistical information and the relevant literature. We also presents previously not published estimates of social assistance receipt among natives and immigrants, as well as of the poverty reducing effects of social assistance both based on the Household Income Survey 2003.

The paper is laid out as follows: In the next section we provide a short description of the immigrant population in Sweden. We inform in Section 3 on how the Swedish social assistance system is constructed. The topic for Section 4 is the norms utilized in the social assistance provision, while Section 5 presents statistical information on the extent of social assistance receipt and policy goals. Statistical information on disparities in social assistance receipt between immigrants and natives are reviewed in Section 6, while Section 7 deals with research on the same issue. Section 8 discusses that the relatively high social assistance receipt among some immigrants can be understood from the perspectives of immigrant's lack of integration in the labor market at the destination, holes in the income safety net and possibly also other factors. Finally Section 9 ends the paper with some concluding comments.

\section{Sweden's immigrant population}


Sweden's experience as immigrant country is relatively recent. At the beginning of World War II very few foreign born persons lived in Sweden, but since then many waves of immigrants have crossed the boarders. While the foreign-born population numbered 1.8 percent in 1950, the proportion had grown to 7.5 percent in 1980. At the end of 2008 1280000 foreign born persons lived in Sweden, which constitutes 13.8 percent of a population numbering in total 9260000 persons. However, in the public debate is the term "immigrant" not restricted to people who are foreign born. Statistics Sweden report that at the end of 200817.9 percent of the population in Sweden, 1661000 persons, had a foreign background. Those numbers includes in addition to persons being born abroad Swedish born having two foreign born parents. The numbers would have been still higher if also native born persons having one foreign born and one native born parent were included. Many foreign born persons and their children have received a Swedish citizenship. At the end of 2008 did the foreign citizens make up 562000 persons or 6.1 percent of the population in Sweden.

\section{/Table 1 about here/}

Using information on the situation in January 2009 Table 1 list the 20 largest sending countries for foreign born to Sweden by name and number. A large heterogeneity in geographical distance to Sweden can be observed. The closest neighboring Nordic countries among which a common labor market has been in place for half of a century is well represented. Finland is the largest sender country of immigrants to Sweden and most such immigrants have a long period of residency at the destination. Furthermore, Denmark rank number eight and Norway number nine. Another group of large sender countries are other members of the European Union, an entity Sweden belongs to since the mid 90s and among which mobility nowadays faces few restrictions. To this group of sender countries counts Poland (rank 4), Germany (rank 7), Great Britain and Northern Ireland (rank 15) as well as Rumania (rank 18). Most migrants from the countries mentioned by name above, as well as those from the United States (rank 19), arrived for labor market reasons or for family reasons. Such a description also fit the migration population from the entity here labeled Yugoslavia, the third largest country of origin. The majority of those people arrived during the 70s.

Iraq counts nowadays the second largest sender country among immigrants to Sweden, a population that has more than doubled since 2000. Most entered Sweden as refugees, for humanitarian reasons or as relatives to family members who had been admitted for such reasons. Such a description also fit the immigration populations born in Iran (a majority arriving during the 80s) and Bosnia-Herzegovina (a majority arriving during the 90s), the fifth and sixth largest sending county. The description also applies to the somewhat less numerous migrant populations from Chile, Somalia, Lebanon and Syria. Table 1 also inform on that Turkey rank number 10 and Thailand number 12 among countries of birth among immigrants to Sweden while the most populous countries in the world, China and India rank 17 and 20.

A considerable proportion of Sweden's more recently arrived immigrants originate from low or middle income countries and have not entered as labor migrants. Few other rich countries have during the later decades admitted equally many asylum seekers and their relatives in relation to their population size as Sweden. A considerable proportion of the recent immigrants is Muslims, and many are by appearance and name easy to distinguish from the majority population. The immigrant population is younger than the native category. Metropolitan areas and larger cities have higher proportions of foreign born than smaller cities and rural areas. 


\section{The provision of social assistance ${ }^{1}$}

To receive social assistance ("Försörjningsstöd”, “Ekonomikt bistånd” previously Socialbidrag) a person typically call the relevant Social Welfare Office. Some, but far from all, calls results in an appointment with a social worker. ${ }^{2}$ The social welfare office is a branch of the local government and it is the local government (with exceptions discussed below) which finances the expenditures of social assistance. In Sweden there are 290 local governments and the rate of social assistance receipt in their population varied in 2008 from 0.4 to 10.6 percent. For followers of Swedish media it comes as no surprise that the local government with the lowest rate of social assistance receipt is Vellinge and the highest one Södertälje. The first mentioned has become infamous for not admitting refugees. ${ }^{3}$ The second has been known for although not having more than 80000 inhabitants it has recently received a larger number of refugees from Iraq than United States and Canada together. ${ }^{4}$

Many local governments serve relatively small populations thus only one social welfare office is necessary, but the larger cities have several social welfare offices. While activities at the social welfare office are overseen by a board of local politicians, an applicant typically meets a social worker; a professional trained at a university or college. This can lead to the person putting in a formal claim. The applicant has to provide information on the structure of his or her family, various sources of income, assets as well as housing expenditures and in some cases other expenditures as well. A typical application refers to a period of one month. After such a meeting the social worker reviews the application which involves checking information provided by the applicant and performing calculations.

Based on the review a decision is taken and communicated to the applicant a few days after application has been handed in. The following is a simplified description of the decisionmaking process ${ }^{5}$ : People with disposable incomes lower than income thresholds laid down in norms and in other guidelines who cannot make a living in any other way receive social assistance. The sum closes the gap between disposable income and the relevant threshold as specified in the norm. The applicant is allowed to appeal the decision. To receive social assistance for a second month a member of the household is required to hand in a new application and the procedure is repeated. There is no time limit for how long a period a household can receive social assistance.

The legal framework for the activities of the Social Welfare Offices consists of several layers. The parliament has passed the Social Welfare Act (originally in effect since 1982) though its present formulation came into work in 2002. This Act regulates a number of local government activities regarding social welfare. Chapter 4 of the Social Welfare Act regulates the individual's right to social assistance. The first paragraph states that persons who cannot meet their needs or have them met in other ways have a right to assistance from the Social Welfare Board for their maintenance (maintenance support, "Försörjningsstöd") or for their livelihood. This version of the act does not use the term "Socialbidrag" which was introduced when the

\footnotetext{
${ }^{1}$ This and the next section summarise and update Gustafsson (2003).

${ }^{2}$ For empirical studies on how the intake functions see Minas (2005, 2006 and 2009)

${ }^{3}$ See Aftonbladet 20091122 http://www.aftonbladet.se/nyheter/article6166209.ab

${ }^{4}$ See Dagens Nyheter 20071122 http://www.dn.se/nyheter/sverige/sodertalje-tar-emot-fler-irakier-an-usa-ochkanada-1.599238

${ }^{5}$ Results for a series of empirical studies using hypothetical identical applications show a rather large variation in decisions. See for example Gustafsson et al. (1993) and Strantz (2007)
} 
law first came into effect 1982 and is still in popular use. The local government is obligated to provide social assistance independent of its financial situation thereby making it illegal to reject an application due to lack of local government resources.

Please note that the Social Welfare Act does not list categories of persons entitled to social assistance. Any person residing in Sweden (regardless of nationality) is eligible with one exception. Practically indistinguishable from Försörjningsstöd / Ekonomiskt bistånd some recent immigrants are instead entitled to a specific benefit ("Introduction fee for refugees and some other foreigners”, "Introduktionsersättning för flyktingar och vissa andra utlänningar") in compliance with a particular act (1992:1068). These benefits are also provided by the local government, and are harmonised with those of the primary system of social assistance. If introduction assistance is provided a contract on integration is made between the local government and the recent refugee. The local government can then recover costs for providing assistance to new refugees from the central government. We will, as is usually the case, treat introduction assistance as a part of the Swedish system of social assistance.

However, we will in the following sections of the paper, as typically the case, not include the system of old age social assistance (“Äldreförsörjningsstöd”) which can be claimed by persons aged 65 and older. Although it is in some aspects similar to Försörjningsstöd / Ekonomiskt bistånd it is administered by the social insurance offices and fully funded by the central government. Most recipients of old age social assistance are foreign born although some Swedish born persons who have returned after a period abroad also receive the benefit (Albertsson, 2008). This system, introduced in 2003, aims to fill holes in the basic penison system, as in its present form a residence record of at least 40 years is required to receive a full basic pension. ${ }^{6}$

The requirement for receipt of social assistance is that the benefit unit possesses a low income together with the inability to earn a living in any other way. A benefit unit consists of one or two adults (married or cohabiting) and their dependent children. A person is considered a child if under age of 18, or if secondary school is not completed. Parents are not legally required to support their adult children, and children are not required to support their parents.

The rules in the Social Welfare Act imply, for example, that a household should try to support itself by paid work, by drawing on savings, or by selling assets. Only if such options are exhausted do not exist is a person eligible for social assistance. The rules also imply that unemployed persons typically have to show that they are registered at the employment office and are actively searching for a job. In a country where paid work is the norm for females (and public child care is heavily subsidised) this also applies to mothers of young children. The second paragraph in chapter 4 of the Social Welfare Act states that the social welfare board is allowed to provide assistance (Ekonomiskt bistånd) in addition to the reasons stated in the first paragraph. Local government thus has the right to top up benefits. ${ }^{7}$

\footnotetext{
${ }^{6}$ A single person over 65 with a monthly disposable income lower than 4831 SEK per month (net of income taxes and housing costs) can be granted the benefit. Statistical information from the Social Insurance office show that in December 200811854 persons received such benefits, and the costs for out-payments during 2008 as a whole was 431 million SEK.

7 One can see this as a throwback to the past when each local government decided on the level for the norm. This was actually the case up to January 1998 when the norm applicable to all the country first came into play.
} 
The third paragraph of chapter 4 of the Social Welfare Act states that maintenance support (Försörjningsstöd) is given for the following costs:

1. Food, clothing and shoes, play and leisure, articles of consumption, health and hygiene and finally daily newspaper, telephone and TV licence. Those items are included in the norm (See Section 4).

2. Housing, electricity, travel to work, home insurance and finally fees for membership in a trade union and unemployment insurance society. Those are calculated on a case by case basis.

The fourth paragraph of the Social Welfare Act states that the social welfare board can demand that persons receiving social assistance take part in certain measures (trainee jobs or other measures to increase competence) if the person has not been offered a suitable labour market policy measure and:

1. is under age 25.

2. Is over age 25 but due to circumstances is in need of measures to increasse competency, or

3. Is studying in a program for which student financial aid is available, but needs maintenance, in-between school terms

If a person refuses to take part in activities assigned without an acceptable excuse income maintenance can be refused or reduced according to the forth paragraph of the Social Welfare Act. The same also applies if the person fails to attend assigned activities without an acceptable excuse.

Some comments can be made on the content of paragraph 4 and those following it. These paragraphs did not have counterparts in the legislation in effect during the 80s and 90s. However, during the 90s with its high unemployment, ever-larger groups of young adults became social assistance recipients, for more on the issue see Salonen (2000). For example, Andrén and Gustafsson (2003) report that at age 22, 15 percent of those native born 1970 had experience of receiving social assistance as an adult. However, among those born in 1975 as many as 30 percent had at the same age had such an experience. Thus there was a strong trend of social assistance becoming a widespread benefit for young adults during the transition to adulthood. This process was triggered by the macroeconomy as unemployment among young adults increased dramatically at the beginning of the 90s (Lundborg, 2000). The new paragraphs of the Social Welfare Act can be regarded as the Swedish version of welfare reform, that is the trend to emphasise activity measures; a trend which is observable in this field of policy in several other countries as well. ${ }^{8}$

While the Social Welfare Act is rather general in its formulation, it is the job of the National Board of Health and Social Welfare ("Socialstyrelsen") to oversee the activities of the social welfare boards. The National Board of Health and Welfare provides information on the norm (decided by the government) as well as detailed advice on how to take decisions on social assistance. It has published recommendations as well as books (Socialstyrelsen 2000, 2003) each filled with more than 200 pages of detailed advices.

\section{Norms defining eligibility}

\section{/Table 2 about here/}

\footnotetext{
${ }^{8}$ Studies that deal with the issue of evaluating activity programs / rules for social assistance receipt are Milton and Bergström (1998), Milton (2000a,b), Hallsten et al (2002), Giertz (2004) and Dahlberg et al (2008).
} 
We will in this section discuss the norms; Table 2 provides information on the levels in effect since January 2009 and applicable to at least December 2010. To compute the norm applicable to a specific benefit unit one has to add up the individual specific amounts and to it the amount defined by the number of persons. This means that the norm for a single person without children amounts to 3680 SEK (per month) and for a couple without children to 6 050 SEK (per month). ${ }^{9}$ If there are dependent children the amounts increase for each additional child, but at a somewhat decreasing rate. Such increases are higher the older the child is. ${ }^{10}$

Are the norms high or low? The answer might differ as different types of comparisons can be made. Seen over a period of one or several generations, and linking the norm to it's previous equivalent, there is no doubt that the norms are much more generous than they were a long time ago, see Rauhut (2002). In contrast it might well the case that since the end of the 1980s has the purchasing power of the norms diminished. Comparisons are not straightforward as previously each local government had it's own norm. However, Stranz (2007) shows based on a study of some local governments that in 2003/2004 a hypothetical applicant would face a norm expressing a lower purchasing power compared to what was the case one decade ago. Consistent with this Johnasson (2001) finds after having investigated changes in the law, regulations from the National Board of Health and Social Welfare and court cases as well as case studies of two local government that during the 90s provision of social assistance became more restricted or at least more selective than before.

We have access to tabulations from the Household Income Survey at Statistics Sweden showing that median income for all households in 2003 was 165913 SEK per equivalent adult. ${ }^{11}$ In contrast, the median for households receiving social assistance at least during one month the same year was 106453 SEK per equivalent adult, this means 64 percent of median for all households. The income level of social assistance recipients thus appears as relatively low.

A norm of 3680 SEK for a single person without children is indeed low when compared to wages for a full-time earner. Statistic Sweden reports monthly gross earning for a full-time worker in 2008. ${ }^{12}$ The median was 24000 SEK. Looking at the lower part of the distribution one observe that Sweden has no official minimum wage. However, we can turn to the earnings level for a cleaner at hotel or office at the $10^{\text {th }}$ percentile (by definition, 90 percent of the population of full-time cleaners earn more); 16500 SEK. We can thus safely conclude that the norm for a single person without children is much lower than the earnings of a person with a low wages, see the following example. Assume that the single low earning person pays 3200 SEK in rent. This would require him or her to have a disposable income of less than 6 880 SEK (gross of housing costs) to pass the income test for social assistance. This can be

\footnotetext{
${ }^{9}$ As of January 2010100 SEK were equal to $9.8 €$ or 14.3 USD.

10 The amounts reported in Table 2 are based on the assumption that children receive a free lunch five days a week when placed in day care centers or involved in primary or secondary education. The National Board of Health and Social Welfare provide breakdowns of the monthly costs covered by the norm. For example for a single adult (year 2009), 1620 SEK is for food and beverages, 520 SEK for clothing and shoes, 400 SEK for leisure activities, and 260 SEK for hygiene. The remaining are for articles of consumption (110 SEK) as well as for daily newspaper, telephone and TV license (770 SEK).

${ }^{11}$ A commonly used equivalence scale in which the first adult person is assigned the value 1.0, each additional adult 0.7 and the value of 0.5 is added for each child under 18 is used.

${ }^{12}$ http://www.ssd.scb.se/databaser/makro/SaveShow.asp Accessed December 1, 2009. For a study on people’s perception of adequate norm for social assistance see Halleröd (2004).
} 
compared to net income for the low-income earner in the example above which is slightly over around 11000 SEK (net of income taxes but gross of housing costs).

However, the situation can look rather different when the benefit unit has several nonworking members. With an increased number of dependent children, the gap between income from employment and the social assistance norm decreases to eventually disappear. The classic issue of conflict between providing incentives to work and support to the needy is in the Swedish context very much related to two parent families with a large number of dependent children as well as to single parents, predominately single mothers.

Two studies have modeled labor supply among single mothers in a framework where the level of the norm for social assistance is considered (Andrén 2003, Flood et al 2003) The results indicate that the level of the norm has a substantial effect on labor supply as well as receipt of social assistance among single mothers. For example a suggested reform reducing income taxes, the level of the social assistance norm and out of pocket payments for public child care (which are income related) is evaluated by Flood et al (2003). The reform would increase incentives for single mothers to work and the simulations indicate a changed labor supply of some mothers as well as a rather large drop in social assistance receipt. Many, but not all single mothers would gain from the reform as their disposable income would increase. Tax and benefit-policies can thus be judged to affect social assistance receipt among single parents. However, pay attention to that this can most likely not be generalized to single persons without children, the largest category of social assistance recipients.

\section{The number of social assistance recipients and policy goal}

Table 3 provides some key numbers of social assistance receipt in Sweden for each year 1983 to 2008 based on publications from Statistics Sweden. The number of recipients, defined as persons living in a household that at least once during a year has received social assistance, has varied between 378000 (2007) and 722000 (1996), or from 4.1 percent of the population to 8,2 percent. While there is no long run trend in the rate of recipients, the extent of social assistance receipt in the population has been shown to be strongly influenced by the unemployment rate (Korpi, 1974, Gustafsson, 1984, Stenberg 1998. On this issue see also Brännström and Stenberg 2007). The deep downturn of the economy in the beginning of the 1990s resulted in an expansion from 1991 to 1996 when the number of recipients grew by 46 percent, average duration by 35 percent and out payments doubled. Thereafter and following the recovery of the economy did the number of recipients and outpayments decrease continuously to year 2007. However, quarterly statistics on out-payments shows that this development turned to it's opposite during 2008 as the recent deep downturn of the world economy hit the Swedish economy. Out-payments of social assistance were for the three month period July - September 200919 percent higher than during the same period 2008. (Socialstyrelsen, 2009)

\section{/ Table 3 about here/}

A worrisome development is that there is a clear trend in periods of receipt being longer, see Table 3. While a household that received social assistance in 1983 were on average on the welfare roles for 4.2 months during a calendar year, the corresponding number had in 2008 increased to 6.1 months, an increase by 45 percent. Almost all of the increase has taken place since the start of the deep economic downturn in the beginning of the 90s. The increased 
length of receipt is an important reason for total out payments in 2008 being larger than during the 1980 s.

In 2001 did the Government present the parliament with the following goal: "The government is now working to increase employment and justice in the society. As a consequence, the number of social assistance recipients should be cut in half between 1999 and 2004.” The goal was accepted by the parliament, and the government stated that each year it would report on how the goal was fulfilled. Ministry of Finance (Finansministeriet, 2001, Addendum 3) provided an operational definition of the goal. The underlying idea was to transform social assistance receipt of various lengths and amounts into full equivalents (full year and full receipt). It refers to households having a head $20-64$ years of age and does not include introductory assistance to newly arrived refugees. This means that the goal was specified to reduce social assistance receipt from 115200 full year equivalence in 1999 to 57600 full year equivalence in 2004.

The first reports to parliament indicated substantial decreases in social assistance receipt since 1999. However, progresses came to a halt as the employment situation in the population worsened and in 2004 was the number of full year equivalence as high as 88000 . Thus the reduction of the number of full time equivalences since 1999 was only 24 percent, not 50 percent meaning that the goal was not fulfilled. (Finansministeriet, Addendum 3, 2006). No attempt to formulate a new explicit goal on reducing social assistance receipt has thereafter been made. ${ }^{13}$ However, a governmental commission has produced a more than 500 page long report with a battery of suggestions aiming to reduce social assistance receipt in the population (SOU 2007:2). In this, as well as in a new report by independent economists (Dahlberg, 2009) some of the proposed measures are directed towards immigrants receiving social assistance. At time of writing it remains to be seen if some of the suggested changes are going to be introduced.

\section{Statistical information on disparities in social assistance use between immigrant and native}

\section{/ Table 4 about here/}

Since some years information on social assistance receipt by nativity is reported in the official statistics. Table 4 presents foreign born and native born recipients by absolute numbers as well as rates of receipt within the relevant population category by age for 2008. It shows that the total number of foreign born recipients is actually slightly larger than the number of native born. The rate of receipt is six times higher among the foreign born than among native born. Generally, rates of receipt are the highest among young adults. As many as 32 percent of foreign born persons aged 18 to 19 were receiving social assistance in 2008, while the corresponding proportion among native born of the same age was only 5 percent. Social assistance receipt is very low among middle aged and older native born persons. The official statistics also show that in 1990 did out-payment to foreign born households amount to 56

\footnotetext{
13 However, for the budget year 2008, information on the number of full time equivalence receivers of government transfers among people in work active ages were reported. (Finansminsteriet, Addendum 3, 2007) Among those a minority is social assistance recipients and thereby the focus was shifted towards measures to reduce the number of receivers in the systems of unemployment compensation, sickness benefits and disability pensions.
} 
percent of all out payments, a number that had increased to 63 percent in 2008. As much as 24 percent of total out payments for social assistance in 2008 can be attributed to what in the statistics in defined as refugee households, that is to households that have received residence permit as refugees or for humanitarian reasons during the year or the three preceding years. A still larger proportion (39 percent of the total) is the out-payments for other foreign born and not more than 37 percent are the out payment to native born.

\section{/Table 5 about here/}

Further information is provided in Table 5 where we use the Household Income Survey at Statistics Sweden for 2003 to report estimated rates of social assistance receipt for natives, second generation of immigrants and first generation of immigrants as well as the number of persons belonging to the various categories. ${ }^{14}$ Among adults do second generation immigrants, particularly those with two foreign born parents, have higher rates of receipt than native born. Among first generation immigrant adults from not rich countries stand out with a rate of receipt as high as 24 percent, to be compared to 3 percent among native born having two parents native born. Looking at rates of social assistance receipt from the perspective of children provides a supplementary view. Not more than 4 percent of native born children having two Swedish born parents lived in a household that received social assistance in 2003. However, the rate was two times as high if one of the parents was foreign born, and not less than 19 percent if both parents were foreign-born. The highest rates were found for children themselves born in not rich countries, among who as many as 38 percent lived in a household that had received social assistance in 2003.

We can use the same data for an accounting exercise in order to find out to what extent social assistance reduces financial poverty as it is conceptualized and measured within the European Union (See Atkinson et al 2002). We draw poverty line at 40 alternatively 50 and 60 percent of the median income and report the proportions falling below them using two different definitions of disposable income: One excluding and one including receipt of social assistance. The difference between the two expresses the poverty reducing effect of social assistance. $^{15}$

\section{/Table 6 about here/}

Reading the content of Table 6 some findings emerge. Rates of poverty (after having considered social assistance receipt) are low among native born, only 6 percent among adults as well as children in case both parents also are native born. This is not due to social assistance, as rather low proportions of native born are taken out of poverty by social assistance. The situation is relatively similar among Swedish adults born having one or two foreign born parents, the second generation of immigrants, although they have higher rates of poverty. However, adults born in not rich countries have definitively high poverty rates (after taking social assistance payments into account): 26 percent. Very similar is the proportion among children born in Sweden having two foreign born parents as well as among children themselves born abroad.

\footnotetext{
${ }^{14}$ For the estimates sampling weights developed by Statistics Sweden are used.

${ }^{15}$ This assumes that social assistance receipt do not affect income of households calculated as not including social assistance. Given the strictness of the means test once can argue this is a reasonably good first approximation.
} 
Table 6 also shows that social assistance makes relatively few immigrants cross a poverty line set at 60 percent of the median income. Social assistance has a much larger influence on immigrant poverty when focusing on the 40 percent of the median income poverty line - deep poverty. Among adults born in a not rich country does social assistance reduce such a proportion from 16 percent to 7 percent. Still larger is the reduction among immigrant children. Rather dramatically the proportion children born in not rich countries that falls under the 40 percent line drops from 21 to 3 percent when social assistance is considered in the calculations. Social assistance must thus be deemed as rather successful in reducing deep poverty among this category. Still it should be remembered that one in four native born children having two foreign born parents as well as among those children themselves foreign born fall under the 60 percent poverty line (after considering receipt of social assistance). This information is important from a policy perspective. It means that measures that aim to increase incentives for immigrants to work by reducing social assistance benefits have a risk of increasing child poverty and thus be in conflict with other policy goals.

\section{Research on disparities in receipt between immigrant and natives}

Given the information provided in the previous section does it not comes as a surprise that the issue of social assistance receipt among immigrants to Sweden has been the subject of several research efforts, efforts that have focused on different aspects of receipt. Table 7 lists not less than 13 academic studies we are aware of that have used household data with an emphasis on shedding light on disparities of social assistance receipt between natives and immigrants. ${ }^{16}$ The table describes the studies by population studied, definition of immigrant, dimension of receipt studied, date and / or period studied as well as main results. With only one exception do all studies refer to the first generation of immigrants. Most studies have used register data for the 90 s.

The two first lines of Table 7 describe the earliest studies. Gustafsson (1986) report that the number of foreign citizens receiving social assistance had been increasing since the mid 60s. During the 70s and beginning of 80s foreign born had higher rates of receipt than the majority population. Rates were comparably high shortly after arrival and among immigrant with a non-Nordic citizenship. Franzén (1997) followed arrival cohorts of foreign born from 1983 to 1992 and found rates of receipt to be high at arrival but thereafter decrease. The cohorts arriving 1988 had higher rates of receipt at arrival than the cohort arriving 1983. Studying a balanced panel for the years 1983 to 1992 it was found that while 11 percent of native born adults hade received social assistance at least once during the ten year period, the proportion was as high as 26 among foreign born.

\section{/ Table 7 about here/}

Several authors have used larger datasets of cross section information and estimated models explaining probabilities of receipt using as key explanatory variables age, years since immigration, education and origin. The third listed study, Hammarstedt (2000) is one example, the fourth listed Franzén (2001) another. ${ }^{17}$ Table 8 report some results from the

\footnotetext{
${ }^{16}$ In addition there are studies in witch rates of receipt at the level of the local government population is studied and that have used variables indicating the proportion of immigrants residing in the jurisdiction. See Byberg (2002) and studies there cited. Generally those studies find a positive association between the rate of immigrant and the rate of social assistance receipt.

${ }^{17}$ Hammarstedt (2000) also studied receipt of some other public transfers.
} 
second mentioned in the form of how predicted probabilities for receipt in 1995 vary by origin, education, and years since immigration for a single woman with no children aged 40 . The table reports that while among natives receipt is rather unlikely for a longer educated person, this is not the case among newly arrived foreign born with the same level of education. Probabilities of receipt diminish rapidly by years since immigration and vary by country of origin. Probabilities of receipt among immigrants originating from rich countries are comparably low, while this is not the case among immigrants from not rich countries. Particularly high are the probabilities for newly arrived immigrants from such countries.

\section{/Table 8 about here/}

Using basically the same framework and similar variables did Hammarstedt and Ekberg (2004), study number 5, investigate social assistance receipt among second generation immigrants and natives in 1997. A major finding is that a non European background led to a higher probability of receipt. Another development of the same type of analysis is to pooled cross section in order to estimate effects of not only years since migration but also of arrival cohort. This was done by Hammarstedt (2009), study number 6, using data for 1990, 1995 and 1999. Also in this study do the results indicate striking differences in probabilities of receipt between immigrants with different origins. Immigrants from rich countries were found to have rates of receipt relatively similar to the native population and they were not found to be affected by years since immigration. In contrast rates of receipt among immigrants from not rich countries are initially high, decrease by years since immigration and have increased across arrival cohorts.

Halleröd (2003), study number 7, represents another variant of the same analytical framework. It is comparative as determinants of receipt 1986-87 as well as 1996-98 are studied. Data comes not only from registers but also from interviews and are in this sense richer than for other similar studies. The results show that when including variables measuring unemployment, income and receipt of transfers do coefficients for variables indicating immigrant status diminish. Still, foreign citizenship lead to higher probabilities of receiving social assistance. The results also shown that a household with given characteristics had lower probabilities of receipt 1996- 98 than in 1986-87. This development can indicate a lower propensity to apply for social assistance or that social assistance has become less generous / more stringent provided. ${ }^{18}$

In two papers have Jörgen Hansen and Magnus Löfström studied social assistance receipt among immigrants and natives using balanced panels of adults and advanced econometric methods. One advantage with the research strategy is that from the onset it is clear that possibly selective return migration, most prevalent among immigrants from rich countries, can not affect results reported (while this might be the case in cross section studies). However, pay attention to that as many as approximately 40 percent all foreign born who live in Sweden 2009 have arrived after 1996, the last year in their data, and are therefore not included in the studies.

Hansen and Löfström (2003), study number 8, estimated a random effects probit model to uncover the patter leading to social assistance receipt. In their analyses are immigrants from countries sending many refugees, all being not rich, treated as a category separated from other immigrants. The results indicate that upon arrival do immigrants from refugee sending

\footnotetext{
${ }^{18}$ These results are in agreement with results from Arslanogullari (2001) who used cross section data for 1990 and 1995 in order to better understand reasons for the expansion of social assistance receipt across the two years.
} 
countries have considerably higher probabilities of receipt than other immigrants who in turn have higher probabilities than natives. By increased years of residency does probability of receipt fall, most quickly among immigrants from refugee sending countries. Immigrants who arrived at the end of the 60s and beginning of 70s have probabilities of receipt similar to the ones for natives only after a relatively long residency. Later arrived cohorts of refugees are predicted to have higher probabilities of receipt compared to earlier arrival cohorts after the same duration of stay, while such differences are smaller for other immigrants.

Hansen and Löfström (2009), study number 9, define the three states receiving social assistance, receiving unemployment compensation and being employed and studied transitions into and out of the three states for males. In the analysis are in addition to natives three categories of immigrants studied: Refugees, Nordic immigrants and Other immigrants. While 8 percent of natives received some social assistance during the period 1990 to 1996, the corresponding proportion among refugee migrants was as high as 37 percent. A dynamic multinominal logit model is estimated controlling for initial conditions and unobserved heterogeneity. The results indicate that particularly refugee immigrants display a greater degree of "structural", or "true" state dependence than natives. The high degree of social assistance receipt among immigrants might be due to the existence of a "welfare trap" due to human capital depreciation or / and that social assistance receipt send a signal to potential employer indicating that the job applicant is less productive. In contrast participation among natives and non-refugee immigrants is reported to be largely due to permanent unobserved characteristics. $^{19}$

All studies surveyed up to now have in common that social assistance receipt is measure using yearly data and a person is defined as a recipient if living in a household that has received assistance at least during one month during a calendar year. This means receipt that last one month is treated the same as receipt with a duration of 12 months within the calendar year. The remaining studies listed in Table 7 have applied other definitions of receipt.

Gustafsson (1998), study number 10, investigated the probability of entering social assistance receipt among males among those who became first time unemployed. Administrative data from the city of Gothenburg, and a 18 month follow up period was used. Results show that a long spell of unemployment, as well as the unemployed person not being eligible to unemployment benefits from an unemployment fund both greatly increases the probability of entering social assistance receipt. With increased age do probabilities of entering receipt decrease. Compared to those circumstances does a foreign citizenship have only small effects on receipt, see Table 9.

\section{/Table 9 about here/}

Gustafsson et al. (2002), study number 11, investigated the length of the status social assistance receipt as well as the length of the state of not reentering into receipt, measured in months for new recipients in an international comparison. Administrative data from cities located in Germany, Italy. Portugal, Spain and Sweden were harmonized and analyzed. A paradox was found: Recipients in cities with more generous benefit levels, that is cities

\footnotetext{
${ }^{19}$ This is consistent with results reported by Nyblom (2008). This author analysed survey data from social workers concerning 372 recipients from four local governments in order to study their perception of barriers clients have to getting and receiving a job. The results showed that lack of education was most frequently often mentioned. Different from for natives barriers related to lack of motivation, lack of self-confidence or a difficult childhood were infrequently brought up for immigrants
} 
located in the north of Europe, were found to have shorter average spells of receipt than cities in the south of Europe where benefits are lower. This is shown in Table 10 where the descriptive results are reported. In some cities did immigrants have longer spells of receipt than natives even after controlling for age and family type. This was particularly the case in the Swedish cities. In contrast, in the Italian cities did immigrants have shorter spells of receipt than natives. This study also showed that a considerable proportion of people who exit social assistance receipt in the Swedish cities re-enter after some months of non-receipt.

\section{/Table 10 about here/}

In Section 5 did we report that the average number of months a household receives social assistance has trended up since the beginning of the 90s. This is a motivation for Bergmark and Bäckman (2004), study number 12, to investigate the dynamics of long term receipt, which the authors defined as receipt that has lasted for at least 10 month during a given calendar year. ${ }^{20}$ Probability models for leaving long term receipt and for reentering long term receipt was estimated using data for 1991 to 1998. The results indicate that controlling for year, age, education, household type and regional unemployment did a short period of residence in Sweden decrease the probability of leaving long term receipt as well as increase the probability of re-entering long term receipt.

The last study for this survey, Mood (2009), study number 13, also investigates long term receipt defined in the same manner. Here the research question is: To what extent has immigrant household contributed to the expansion in the total number of long term recipients from 1990 to 2003? Using data from the capital Stockholm the author decomposes the increased long term receipt into three terms: Changes in the proportion of immigrants in the city, changes in long dependence among immigrant and changes in long dependence among natives. The results show that almost half of the increase in long term receipt can be attributed to increased proportion of immigrants in the population and a slightly lower proportion to increased long time dependence among immigrants. In contrast increased long term dependency among natives contributed only marginally to the total increase in long-term social assistance receipt in the total population.

Results from the surveyed studies most often point in the same direction. Social assistance receipt among immigrants is relatively high shortly after immigration, but typically diminishes with years since immigration. There is much of heterogeneity in receipt between immigrants due to country of origin. The highest probabilities of receipt are found among immigrants from not rich countries from which many have entered as refugees, for similar reasons or due to family reasons. Studies that have investigated it have found that later arrival cohorts of immigrants tend to have higher rates of receipt than earlier arrived cohorts.

\section{Immigrants in labor market and the income safety net}

Following the literature and the general perception we claim that the relatively high use of social assistance among immigrants to Sweden can best be understood from the perspectives of immigrant's lack of integration in the labor market at the destination. To a certain degree holes in the income safety net also play roles. Additional causes for a comparatively high rate

\footnotetext{
${ }^{20}$ Since 2002 does the register of social assistance receipt at Statistics Sweden contain information on during which specific month during a calendar year social assistance is received. This will make more detailed studies on social assistance receipt possible, on this see Bergmark and Bäckman (2007)
} 
of social assistance receipt among immigrants is the demographic composition: A larger proportion of the foreign population are young adults or live in households with many children, categories in which social assistance receipt is above average. Furthermore it seems likely that immigrants own fewer assets and have lesser access to financial support from relatives and friends. ${ }^{21}$ To this can be added that, disproportionally many immigrants reside in locations where relatively many households receive social assistance, and this might increase knowledge on the program as well as diminish stigma of becoming a recipient. ${ }^{22}$

As Sweden's immigration population has grown in number and its labor market situation has become more worrisome, so has academic research on the topic expanded. For overview of the research filed see for example Ekberg (ed) (2004), Bengtsson et al. (2005) and Ekonomisk Debatt (2007). Although studies have focused on different labor market outcomes, on people of different origins and refer to different years, it is possible to tease out some key lessons from the research.

One lesson, far from unique to Sweden, is that the labor market status of immigrants typically improves with years since immigration. This is consistent with typical findings in the research surveyed in the preceding section that rates of social assistance typically decrease with years since immigration. While immigrants assimilate into the labor market at the destination, in the Swedish case they also assimilate out of social assistance receipt. Another lesson is that studies based on large sets of more recent register data show that observed individual characteristics cannot fully explain gaps in labor market position between natives and immigrants, nor the deteriorating relative situation of immigrants. In contrast, among people in any given job there seems to be very little evidence of wage discrimination. Furthermore, there are no sign of immigrants being less active in the job search. Still they have higher unemployment rates and longer spells of unemployment.

An important lesson from the research is that the main reason for immigrant's unfavorable labor market status seems to be that they are less likely to be hired than natives. Results of several new field experiments show that a foreign name substantially decreases the probability to be called to an interview with a potential employer, see for example Attström (2007), Carlsson and Rooth (2007), Bursell (2007) or Ahmed and Ekberg (2009) the latter surveying field experiments also in other markets. Consistent with this register based research indicate that when an immigrant change his or her name to one signaling nativity this leads to higher income (Arai and Skogman Thoursie, 2009). Furthermore, Åslund et al (2009) show that immigrants are severely underrepresented among managers and that hiring pattern of immigrant managers and native managers are very different; immigrant managers recruited immigrants to a much higher extent compared to what other managers did.

While some kind of consensus seems to emerge on that the hiring decisions is a, or perhaps the, main reason for present labor market gaps between immigrants and natives in Sweden, it leads to new questions. Why do potential employers today discriminate towards job applicants with characteristics signaling foreignness, while for example during the 1950s employer's

\footnotetext{
${ }^{21}$ There is clear evidence that for many households in Sweden, applying for social assistance is considered an unattractive alternative. For an empirical study of this see Gustafsson (2002)

${ }^{22}$ Analysing parish data for persons aged 20 - 251990 to 1999 living in Stockholm Mood (2004) finds that rates of outflow from social assistance receipt as well as rates of inflow into social assistance receipt are affected by the level of social assistance receipt. Using a quasi experimental design Åslund and Fredriksson (2009) finds based on register data for 1990 to 2000 that social assistance dependency among refugees increases if the individual is initially placed in a parish with high rate of social assistance receipt.
} 
actively recruited foreign labor? One line of reasoning attributes much explanatory power to technical and organizational change. Today, there is much less demand for unqualified manual labor which is easy to transfer from one social environment to another. The knowledge based economy requires for example language skills and cultural competence which in many cases is not easily portable across national boarders.

Furthermore, collective bargain has resulted in relatively high minimum wages in Sweden, reducing the demand of for example people who do not master the Swedish language. One could argue that in a hypothetical situation with a larger number of low paid jobs, a higher proportion of immigrants would have been employed. The problem with putting this forward as a policy advice is that trade unions goals are rather the opposite; to reduce wage differences. Alternative policy strategies are therefore more in line with traits of the Swedish model, a model which to a large extent can bee seen as the outcome of trade union action. One strategy of making the immigrant labor force more attractive is to upgrade it's skills, another is to subsidized immigrant employment. Both measures incur costs for the public sector budget, and measured by in this way does the Swedish integration policy stand out as rather ambitious in international comparisons. Still most rich countries face smaller immigrant - native unemployment gap as Sweden, a paradox.

We now turn to the income safety net. The Swedish system of unemployment insurance has a long history and is strongly related to the trade unions. Although formally different from the public sector, unemployment insurance societies are mainly funded by public resources. In addition, eligibility criteria and benefit levels are decided by the parliament after proposals from the government. To be eligible to unemployment benefits a worker must have a work record, actively search for work and be registered at the employment office. Benefits can be received during a period of 300 working days (450 days for parent to children under 18), after which they are terminated.

The maximal unemployment benefit can amount up to 680 SEK (gross of income tax) per working day five days a week. This means that for some workers as much as 80 percent of income losses due to a layoff are replaced. Furthermore, workers placed in labor market programs receive benefits computed according to the same formula, although the benefit is labeled "Activity support” and is paid by the Social Insurance Office.

However, other categories unemployed receive lower benefits. Some, due to lower previous earnings, are eligible to not more than the minimum level of 320 SEK (gross of income tax) per working day five days a week, and there are people in labor market policy measures who receive as little as 233 SEK (gross of income tax) per working day a week. This means that single persons having only such incomes will earn less than the norms used when assessing applications for social assistance (see Section 4). Still other categories of unemployed do not receive any unemployment benefit at all: People who have no previous work record, those who search for a short part time job, those who have not registered at the employment office as well as those who are not active enough in their job search.

In short, one can say that the Swedish system of unemployment insurance in many respects works well for the insiders of the labor market, but not for outsiders. The latter category includes many recent immigrants, as well as school leavers. The situation is similar for the systems replacing income losses due to sickness and due to parental leave. While many native who becomes sick or a parent can count on relatively generous benefits, this is not the case for 
many immigrants experiencing the same events, as they have not previously established themselves in the labor market.

Furthermore, there is evidence that something similar is the case when it comes to access to labor market programs funded by the central government. (Lindmark, 2009) The shortcomings of the central government organized and funded labor market policy has since the 90s motivated many local governments to introduce their own labor market programs for social assistance recipients. (Ulmestig, 2007, Thorén, 2008). However, it appears that up to now progress in finding successful such measures that have been documented in a credible manner is lacking (Lundin, 2008).

\section{Final comments}

This paper has aimed to provide a review of knowledge on social assistance receipt among immigrants in relation to receipt among natives in Sweden. We have described the immigrant population, the system of social assistance, provided statistical information on social assistance use by immigrants and natives as well as surveyed academic studies. Based on research we have also discussed how to interpret the findings.

It has been shown that in present Sweden most of the out-payments for social assistance refer to foreign born persons a category make up 14 percent of the total population. This means that immigrants have considerably higher rates of receipt than natives. Immigrants also have longer periods of receipt than natives. To some extent can the high costs for social assistance received by immigrants be attributed to the need for maintaining refugees when they are newly arrived and during a few years thereafter. However, this is far from the entire story. Not only refuge immigrants have elevated rates of receipt at entry to Sweden. Although there seems to be a general pattern of immigrants to assimilate out of social assistance receipt, receipt continues to be higher than among in several characteristics identical natives many years after immigration among immigrants from not rich countries who have arrived during later decades.

All evidence point towards that the elevated probabilities of social assistance receipt among immigrants from not rich countries are mainly due to failures of integrating into the labor market at the destination. In this sense does the high share of expenditures for immigrant social assistance mirror the problems migrants from not rich countries meet when trying to find a job. Policies for integrating immigrants into the labor market are also policies for reducing social assistance receipt among immigrants. Such policies can aim to make immigrants more attractive to hire due to increasing their human capital, or by subsidizing wage costs. However, we have here referred to results from new research that convincingly indicating that at the hart of problem is also the behavior of the person who recruits workers, typically a majority person. Measures to combat discrimination of immigrants at the labor are also measures to reduce social assistance receipt among immigrants. The integration policy should therefore not be a one sided task for the migrants, but also a task for the majority population.

The Swedish social welfare model is a model where one qualifies by performing paid work. One could claim that in very few other countries are workers who face events like layoffs, sickness, invalidity and parenthood equally well protected from income losses. In contrast people who have no or only week work histories are referred to the last income safety net: 
social assistance. From this perspective it can be claimed that disparities in social assistance receipt between immigrants and the majority are due to the ambitious transfer systems. Similarly one could rightly claim that a fundamental reason for the large number of immigrant social assistance recipients is that they have been admitted to the country as refugees, for humanitarian reasons or as relatives to such persons. However, rolling back the welfare state as well as admitting dramatically fewer immigrants from not rich countries are not politically feasible measures to reduce the disparity in social assistance receipt between immigrants and the majority.

We are thus arguing that the main strategy for reducing the gaps in social assistance receipt between immigrants and the majority can not be changes in the income safety net. Still, such changes can be motivated. For example labor market policy programs could be developed and better targeted towards immigrants receiving social assistance. Among social workers processing social assistance claims there seems to be a wide spread feeling that their clients are not always given the best treatment at the employment offices. We have also presented evidence indicating that in case social assistance norms were reduced in order to increase incentives to work, there is a large risk that poverty among immigrant children would worsen from a level already high. This speaks against a strategy of reducing social assistance receipt among immigrants by only focus on the generosity in the system of social assistance. 


\section{References}

Ahmed, A. and Ekberg, J. (2009) "Fältexperiment för att studera etnisk diskriminering på den svenska arbets- och bostadsmarknaden”, Socialvetenskaplig Tidskrift, 16, (2), 105 - 122.

Albertsson, M. (2008) Från socialbidrag till äldreförsörjningsstöd. En reform ur äldre invandrares perspektiv, Växjö: Växjö universitet, Rapportserie i socialt arbete. Nr 2, 2008.

Andrén, T. (2003) "The choice of paid childcare, welfare, and labor supply of single mothers", Labour Economics, 10, 133 - 147.

Andrén, T \& Gustafsson, B. (2004) "Patterns of social assistance receipt in Sweden" International Journal of Social Welfare, 13 (1), 55 - 68.

Åslund, O., Hensvik, L. and Nordström Skans, O. (2009) "Seeking Similarity: How Immigrants and Natives Manage at the Labor Market”, Institute for the study of Labour, Discussion Paper no 4640.

Arrai, M. and Skogman Thoursie, P. (2009) “"Renouncing Personal Names: An Empirical Examinationn of Surname Chagne and Earnigns”, Journal of Labor Economics, 27, 127 147.

Arslanogullari, S. (2000) Household Adjustment to Unemployment, Univeristy of Uppsala, Economic Studies 49, Uppsala.

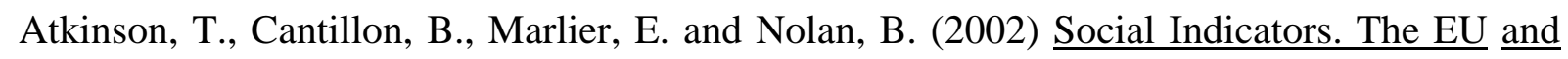
Social Inclusion, Oxford: Oxford University Press.

Attström, K. (2007) Discrimination against Native Swedes of Immigrants Origin in Access to Employment, Genève: International labour Office.

Bengtsson, T., Lundh, C., and Scott, K. (2005) "From Boom to Bust: The Economic Integration of Immigrants in Postwar Sweden" Chapter 2 in Zimmermann, K.F. (Ed) European Migration. What Do We Know?, Oxford: Oxford University Press.

Bergmark, Å. and Bäckman, O. (2004) "Stuck with Welfare? Long-term Social Assistance Recipiency in Sweden”, European Sociological Review, 20 (5), 425 - 443.

Bergmark, Å. and Bäckman, O. (2007) ”Socialbidragstagandets dynamik - varaktigheter och utträde från socialbidragstagandet under 2000-talet”, Socialvetenskaplig Tidskrift, 14, 153 134.

Brännström, L. and Stenberg, S $\AA$ (2007) "Does Social Assistance Receipiency Influence Unemployment? Macro-lvel Findings from Sweden in a Period of Turbulence", Acta Sociologica, 50 (4), $347-362$.

Bursell, M. (2007) "What is a name? A Field Experiment Test for the Existence of Ethnic Discrimination in the Hiring Process", Working Paper, Stockholm University Linnaeus Centrum for Integration Studies, 2007:7. 
Byberg, I. (2002) Kontroll eller handlingsfrihet? - en studie av organiseringens betydelse i socialbidragstagandet, Stockholm: Stockholms universitet: Institutionen för socialt arbete Rapporter i socialt arbete 101.

Carlsson, M. and Rooth, D-O (2007) "Evidence of Discrimination in the Swedish Labour Market using Experimental data”, Labour Economics, 14 (4) 716 - 729.

Dahlberg, M. Johansson, K. and Mörk, E. (2008) "On the Mandatory Activation of Welfare Receivers", Uppsala: The Institute for Labour Market Policy Evaluation, Working Paper 2008:24.

Dahlberg, M., Edmark, K., Hansen, J. and Mörk, E. (2009) ”Fattigdom i folkhemmet - från socialbidrag till självförsörjning”, Uppsala: The Institute for Labour Market Policy Evaluation, Rapport 2009:4.

Ekberg, J. (Ed) (2004) Egenförsörjning eller bidragsförsörjning? Invandrarna, arbetsmarkanden och välfärdsstaten. Rapport till Integrationspolitiska maktutredningen, Stockholm: Statens Offentliga Utredningar (SOU 2004:21).

Ekonomisk Debatt (2007) Temanummer: Invandrares integration på arbetsmarknaden, No 3, Stockholm.

Finansdepartementet (2001) (Ministry of Finance) Avstämning av målet om en halvering av antalet socialbidragsberoende mellan åren 1999 och 2004. Bilaga 3 till Prop 2001/02, Stockholm.

Finansdepartementet (2006) (Minsitry of Finance) Budgetpropostionen för 2007. Fördelningspolitisk redogörelse. Bilaga 3 till Prop 2006/7:1, Stockholm.

Finansdepartementet (2007) (Ministry of Finance). Fördelningspolitisk redogörelse, Bilaga 3 till Prop 2007/08:1, Stockholm.

Flood, L., Pylkkänen, E. and Wahlberg, R. (2003) "From Welfare to Work: Evaluating a Proposed Tax and Benefit Reform Targeted at Single Mothers in Sweden”, Journal of Human Resources.

Franzén, E. (1997) ”Invandrare och socialbidrag”, Socialvetenskaplig Tidskrift, 4, 279 - 304.

Franzén, E. (2001) "Socialbidrag bland invandrare: Erfarenheter från Sverige”, Sociologisk Forsknig, 38, (3-4), 9 - 39.

Gustafsson, B. (1984) "Macroeconomic performance, old age security and the rate of social assistance receipt in Sweden", European Economic Review, 26, 319 - 338.

Gustafsson, B. (1986) "International Migration and Falling into the Income Safety Net", International Migration, 24, 461 - 483.

Gustafsson, B. (1998) "From the employment office to the social welfare office: Social asistance receipt among first-time unemployed in Sweden", European Journal of Social Work, 1 (2) $203-220$. 
Gustafsson, B (2002) Assessing non-use of social assistance", European Journal of Social Work, 5, (2) 149 - 158.

Gustafsson, B. (2003) "Social Assistance in Sweden", in Final Report - Volume II. Internatinal Experiences with Social Assistance Schemes - Five Country Case Studies, Astana, Internatial Labour Office (ILO) and UNDP Country Office in the Republic of Kazakhstan.

Gustafsson, B., Hydén, L -C. and Salonen, T. (1993) "Decision-making on social assistance in major cities in Swedish", Scandinavian Journal of Social Welfare, 2, 197 - 203.

Gustafsson, B., Mueller, R., Negri, N. and Voges, W. "Paths Through (and out of) Social Assistance” in Saracceno, C. Ed (2002) Social Assistance Dynamics in Europe. National and local poverty regimes, Bristol: Policy Press.

Halleröd, B. (2003) "Varför får folk socialbidrag? Analys av socialbidragstagandets bestämningsfaktorer”, Socialvetenskaplig Tidskrift, 10 (2/3) 238 - 266.

Halleröd, B. (2004) ”What I Need and What the Poor Deserves: Analyzing the gap between the minimum income needed for oneself and the view of an adequate norm for social assistance”, Social Forces, 83 (1), 35 - 59.

Hallsten, L., Isaksson, K. and Andersson, H. (2002) "Rinkeby Arbetscentrum verksamhetsidéer, genomförande och sysselsättningseffekter av ett projekt för långtidsarbetslösa invandrare”, Rapport 2002:10. Uppsala: The Institue for Labour Market Policy Evaluation.

Hammarstedt, M. (2000) "The Receipt of Transfer Payments by Immigrants in Sweden”, International Migration, 38 (2), 239-268.

Hammarstedt, M. and Ekberg, J. (2004) "Unemployment Compensation and the Use of Social assistance among Second-generation Immigrants in Sweden”, International Journal of Social Welfare, 13 (3), 254-265.

Hammarstedt, M. (2009) "Assimilation and Participation in Social Assistance among Immigrants”, International Journal of Social Welfare, 18 (1), 85 - 94.

Hansen, J. \& Lofstrom, M. (2003) "Immigrant Assimilation and Welfare Participation.", Journal of Human Resources, XXXVIII, 74 - 98.

Hansen, J. and Lofstrom, M. (2009) "The Dynamics of Immigrant Welfare and Labour Market Behavior”, Journal of Population Economics, 22, 941 - 970.

Johansson, H. (2001) I det sociala modborgarskapets skugga. Rätten till socialbidrag under 1980- och 1990-talen, Lund: Arkiv förlag (Lund Studies in Social Welfare).

Korpi, W. (1974) "Poverty, social assistance and social policy in postwar Sweden", $\underline{\text { Acta }}$ Sociologica, no 2 - 3. 
Lindmark, S. (2009) ”Af särbehandlar arbetslösa med socialbidrag - om dolda utestängningsprocesser ovärdiga en demokrati”, Socialvetenskaplig Tidskrift, 16, (1) 75 - 83.

Lundborg, P. (2000) "Nittiotalets förlorare", Arbetsmarkand \& Arbetsliv, vol 6, 235 - 48.

Lundin, M. (2008) Kommunerna och arbetsmarknadspolitiken, Uppsala: The Institue for Labour Market Policy Evaluation (IFAU) 2008:13.

Milton, P. (2000a) "Mind the Gap. Translating Practice Problems into Research Questions in an Evaluation of a Welfare Program”, European Journal of Social Work, 3 (1) 25 - 28.

Milton, P. (2000b) ”När man vill veta hur det går för klienterna. Att använda akter i utvärdering av socialbidragsarbetets effekter”, Socialvetenskaplig Tidskrift, 7, (4),361 - 375.

Milton, P. \& Bergström, R. (1998) Uppsalamodellen och socialbidragstagarna. En effektutvärdering, Stockholm: Socialstyrelsen: Centrum för utvärdering av socialt arbete.

Minas, R. (2005) "Shifting the Wheat from the Chaff - The Organization of Telephone Intake and the Selection of Social Assistance Inquires in Sweden", European Journal of Social Work, 8 (2), $145-164$.

Minas, R. (2006) "Intake strategies: Organising the intake of new social assistance inquires”, International Journal of Social Welfare, 15 (1), 63 - 74.

Minas, R. (2009) "Social Expenditures and Public Administration: Are Local Social Assistance Costs in Sweden a Matter of Orgnaization?”, International Journal of Social Welfare, Published on line 24 April 2009.

Mood, C. (2004) "Social Influence Effects on Social Assistance Recipiency", Acta Sociologica, 47, 235 - 251.

Mood, C. (2009) "Lagging Behind in Good Times: Immigrants and the Increased Dependence on Social Assistance in Sweden”, International Journal of Social Welfare, available on line

Nybom, J. (2008) “Hur bedömer socialarbetarna socialbidragstagares försörjningshinder?”, Socialvetenskaplig Tidskrift, 15, 152 - 169.

Organisation for Economic Co-Operation and Development (2008) Growing Unequal? Income Distribution and Poverty in OECD Countries, Paris.

Organisation for Economic Co-Operation and Development (2009) OECD Factbook 2009: Economic, Environmental and Social Statistics, Paris.

Rauhut, D. (2002) Fattigvård, socialbidrag och synen på fattigdom i Sverige 1918 - 1997. Lund: Lund Studies in Economic History 18.

Salonen, T. (2000) "Ungdomars socialbidragstagande och försörjningssvårigheter under 1990talet in Bergmark, Å (Editor) Välfärd och försörjning. Antologi Kommittén Välfärdsbokslut, Stockholm: SOU 2000:40. 
Socialstyrelsen (National Board of Health and Social Welfare) (2000) Handbok om ekonomiskt bistånd, Stockholm.

Socialstyrelsen (National Board of Health and Social Welfare) (2003A) Ekonommiskt bistånd. Stöd för rättstillämpning och handläggning av ärenden i den kommunala socialtjänsten, Stockholm.

Socialstyrelsen (National Board of Health and Social Welfare) (2003B) Ekonomiskt bistånd. Årsstatistik 2002 (Statistik Socialtjänst 2003:8) Stockholm.

Socialstyrelsen (National Board of Health and Social Welfare) (2009A) Riksnormer för försörjningsstöd 2010 - Ändraingar i socialtjänstförordningen (2001:937). Meddelandeblan, Stockholm.

Socialstyrelsen (National Board of Health and Social Welfare) (2009B) Ekonomiskt bistånd. Årsstatistik 2009 Stockhlom.

Socialstyrelsen (National Board of Health and Social Welfare) (2009C) "Ekonomiskt bistånd, kvartal 1 - 3 år 2009, Stockholm.

Statistics Sweden (2009) Tabeller över Sveriges Befolkning 2008, Stockholm.

Sveriges Offentliga Utredningar (2007) Från socialbidrag till arbete, SOU 2007:2, Stockholm.

Stenberg, S - Å (1998) "Unemployment and economic hardship - A combined macro- and micro analysis of the relationship between unemployment and means-tested social assistance in Sweden", European Sociological Review, 14, 1 - 13.

Stranz, H. (2007)_Utrymme för variationer: - Om prövning av soicalbidrag, Stockholm: Stockholms Universitet, Institutiojnen för Socialt Arbete, Rapporter i socialt arbete 119.

Thorén, K. (2008) ”Activation Policy in Action”. A Street-Level Study of Social Assistance in the Swedish Welfare State”, Växjö, Växjö University Press, Acta Wexionensia nr 163.

Ulmestig, R. (2007) På gränsen till fattigvård? En studie om arbetsmarknadspolitik och socialbidrag, Lund: Lund Disertations in Social Work no 27. 
Table 1

Number of foreign-born persons residing in Sweden January 1 2009, 20 largest sending countries

\begin{tabular}{lrll}
\hline Country of birth & Number & Country of birth & Number \\
\hline Finland & 175113 & Chile & 28118 \\
Iraq & 109446 & Thailand & 25858 \\
Yugoslavia & 72285 & Somalia & 25159 \\
Poland & 63822 & Lebanon & 23291 \\
Iran & 57663 & Great Britain and & 19460 \\
& & Northern Ireland & \\
Bosnia - & 55960 & Syria & 18786 \\
Herzegovina & & & \\
Germany & 46854 & China & 18256 \\
Denmark & 46167 & Rumania & 17352 \\
Norway & 44310 & United States & 15901 \\
Turkey & 39230 & India & 15263 \\
\hline
\end{tabular}

Source: Statistics Sweden (2009). 


\section{Table 2}

\section{Norms for social assistance in effect since January 2009}

Individual part

\begin{tabular}{|c|c|}
\hline Age of person & $\begin{array}{l}\text { SEK per } \\
\text { month }\end{array}$ \\
\hline$<1$ year & 1520 \\
\hline 1 - 2 years & 1710 \\
\hline 3 years & 1370 \\
\hline 4 - 6 years & 1640 \\
\hline 7 - 10 years & 2100 \\
\hline 11 - 14 years & 2410 \\
\hline 15 - 18 years & 2710 \\
\hline 19 - 20 years & 2740 \\
\hline Single adult & 2800 \\
\hline Married or cohabiting adults & 5060 \\
\hline
\end{tabular}

Part dependent of household size

\begin{tabular}{lc}
\hline $\begin{array}{l}\text { Number of household members (adults } \\
\text { as well as children) }\end{array}$ & SEK per month \\
\hline 1 & 880 \\
2 & 990 \\
3 & 1240 \\
4 & 1420 \\
5 & 1620 \\
6 & 1850 \\
7 & 2002 \\
8 and more & $2002+170$ SEK for each person on \\
& addition to number 7 \\
\hline
\end{tabular}

Note: At the exchange rate prevailing in October 20031 SEK is equal to $0.11 \mathrm{EUR}$, alternatively 0.13 USD or 14.7 JPY.

Source: Soicalstyrelsen (2009). 
Table 3

Social assistance in Sweden 1983 - 2008, some key numbers

\begin{tabular}{|c|c|c|c|c|}
\hline Year & $\begin{array}{l}\text { Number of } \\
\text { recipients } \\
\text { (thousands) }\end{array}$ & $\begin{array}{l}\text { Rate of recipients } \\
\text { Percent of the } \\
\text { population }\end{array}$ & $\begin{array}{l}\text { Average number } \\
\text { of months of } \\
\text { receipt }\end{array}$ & $\begin{array}{l}\text { Total sum } \\
\text { Million SEK } \\
\text { (Prices for year } \\
\text { 2008) }\end{array}$ \\
\hline 1983 & 475 & 5.7 & 4.2 & 5160 \\
\hline 1984 & 524 & 6.3 & 4.2 & 5787 \\
\hline 1985 & 536 & 6.2 & 4.4 & 6538 \\
\hline 1986 & 564 & 6.5 & 4.5 & 7442 \\
\hline 1987 & 540 & 6.2 & 4.4 & 7441 \\
\hline 1988 & 524 & 6.0 & 4.3 & 7090 \\
\hline 1989 & 505 & 5.7 & 4.3 & 6907 \\
\hline 1990 & 492 & 5.7 & 4.3 & 6835 \\
\hline 1991 & 511 & 5.9 & 4.4 & 7464 \\
\hline 1992 & 560 & 6.5 & 4.6 & 9062 \\
\hline 1993 & 642 & 7.4 & 4.8 & 10753 \\
\hline 1994 & 696 & 7.9 & 5.1 & 12426 \\
\hline 1995 & 689 & 7.8 & 5.4 & 12719 \\
\hline 1996 & 722 & 8.2 & 5.7 & 13938 \\
\hline 1997 & 718 & 8.1 & 5.8 & 14421 \\
\hline 1998 & 660 & 7.4 & 5.8 & 13347 \\
\hline 1999 & 581 & 6.6 & 5.8 & 12169 \\
\hline 2000 & 522 & 5.9 & 5.8 & 10974 \\
\hline 2001 & 469 & 5.3 & 5.7 & 9796 \\
\hline 2002 & 434 & 4.9 & 5.8 & 9397 \\
\hline 2003 & 418 & 4.7 & 5.6 & 8944 \\
\hline 2004 & 417 & 4.6 & 5.7 & 9354 \\
\hline 2005 & 407 & 4.5 & 5.8 & 9202 \\
\hline 2006 & 392 & 4.3 & 5.9 & 9212 \\
\hline 2007 & 378 & 4.1 & 6.0 & 9166 \\
\hline 2008 & 384 & 4.2 & 6.1 & 9465 \\
\hline
\end{tabular}

Source: Socialstyrelsen (2003B) and Socialstyrelsen (2009B).

Note: There are various breaks in the times series documented in the publications. For example up until 1989 people who received social assistance in more than one local government (for example due to migration) were counted more than once. Since 1993 does the statistics include introduction compensation to refugees and some other foreigners. 


\section{Table 4}

Social assistance receipt by age and country of birth 2008. Number and rates among adult recipients.

\begin{tabular}{llccc}
\hline $\begin{array}{l}\text { Age } \\
\text { (years) }\end{array}$ & $\begin{array}{l}\text { Native } \\
\text { born } \\
\text { Number }\end{array}$ & $\begin{array}{l}\text { Native } \\
\text { born } \\
\text { Percent }\end{array}$ & $\begin{array}{l}\text { Foreign- } \\
\text { born } \\
\text { Number }\end{array}$ & $\begin{array}{l}\text { Foreign } \\
\text { born } \\
\text { Percent }\end{array}$ \\
\hline $18-19$ & 11734 & 5 & 8300 & 32 \\
$20-24$ & 29813 & 6 & 17858 & 20 \\
$25-29$ & 15336 & 3 & 17386 & 14 \\
$30-39$ & 20182 & 2 & 34344 & 14 \\
$40-49$ & 22032 & 2 & 29013 & 12 \\
$50-59$ & 14490 & 1 & 17826 & 10 \\
$60-64$ & 4017 & 1 & 5847 & 8 \\
$65-74$ & 2773 & $<1$ & 3555 & 3 \\
$75-$ & 2126 & $<1$ & 1656 & 2 \\
Total & 122503 & 2 & 135786 & 12 \\
\hline
\end{tabular}

Source: Socialstyrelsen (2009B). 


\section{Table 5}

Estimated number of recipients and rates of social assistance receipt among adults and children 2003.

\begin{tabular}{|c|c|c|}
\hline & $\begin{array}{l}\text { Number of persons in the } \\
\text { population. } \\
\text { Thousands }\end{array}$ & $\begin{array}{l}\text { Rate of receipt } \\
\text { Percent }\end{array}$ \\
\hline $\begin{array}{l}\text { Adults } \\
\text { Native born }\end{array}$ & 6574 & 3.9 \\
\hline Both parents born in Sweden & 4363 & 2.9 \\
\hline $\begin{array}{l}\text { One parent born in Sweden } \\
\text { one parent foreign born }\end{array}$ & 309 & 4.0 \\
\hline $\begin{array}{l}\text { Both parents foreign born } \\
\text { Foreign born }\end{array}$ & 140 & 7.5 \\
\hline Born in rich countries & 542 & 6.9 \\
\hline Born in not rich countries & 293 & 23.7 \\
\hline $\begin{array}{l}\text { Children } \\
\text { Native born }\end{array}$ & 2059 & 7.0 \\
\hline Both parents born in Sweden & 1576 & 3.9 \\
\hline $\begin{array}{l}\text { One parent born in Sweden } \\
\text { one parent foreign born }\end{array}$ & 215 & 8.3 \\
\hline $\begin{array}{l}\text { Both parents foreign born } \\
\text { Foreign born }\end{array}$ & 167 & 19.3 \\
\hline Born in rich countries & 48 & 22.4 \\
\hline Born in not rich countries & 53 & 38.3 \\
\hline
\end{tabular}

Note: Estimates based on the Household Income Survey conducted by Statistics Sweden. 
Table 6

Estimated poverty reducing effect of social assistance for various population groups, 2003. Percent of population groups under a poverty line.

\begin{tabular}{|c|c|c|c|}
\hline $\begin{array}{l}\text { Population group and } \\
\text { assumptions }\end{array}$ & $\begin{array}{l}40 \text { percent of median } \\
\text { income }\end{array}$ & $\begin{array}{l}50 \text { percent of median } \\
\text { income }\end{array}$ & $\begin{array}{l}60 \text { percent of median } \\
\text { income }\end{array}$ \\
\hline \multicolumn{4}{|l|}{ Adults } \\
\hline \multicolumn{4}{|l|}{$\begin{array}{l}\text { As if no receipt of } \\
\text { social assistance }\end{array}$} \\
\hline \multicolumn{4}{|l|}{ Native born } \\
\hline $\begin{array}{l}\text { Both parents born in } \\
\text { Sweden }\end{array}$ & 2.6 & 4.0 & 6.4 \\
\hline $\begin{array}{l}\text { One parent born in } \\
\text { Sweden one parent } \\
\text { foreign born }\end{array}$ & 3.5 & 4.8 & 8.3 \\
\hline $\begin{array}{l}\text { Both parents foreign } \\
\text { born }\end{array}$ & 5.8 & 8.0 & 11.8 \\
\hline \multicolumn{4}{|l|}{ Foreign born } \\
\hline Born in rich countries & 5.5 & 8.8 & 15.4 \\
\hline $\begin{array}{l}\text { Born in not rich } \\
\text { countries }\end{array}$ & 16.1 & 22.1 & 31.8 \\
\hline \multicolumn{4}{|l|}{$\begin{array}{l}\text { When considering } \\
\text { receipt of social } \\
\text { assistance }\end{array}$} \\
\hline $\begin{array}{l}\text { Both parents born in } \\
\text { Sweden }\end{array}$ & 2.0 & 3.3 & 6.1 \\
\hline $\begin{array}{l}\text { One parent born in } \\
\text { Sweden one parent } \\
\text { foreign born }\end{array}$ & 3.1 & 4.6 & 8.0 \\
\hline $\begin{array}{l}\text { Both parents foreign } \\
\text { born }\end{array}$ & 4.4 & 5.9 & 10.5 \\
\hline \multicolumn{4}{|l|}{ Foreign born } \\
\hline Born in rich countries & 2.9 & 5.7 & 13.3 \\
\hline $\begin{array}{l}\text { Born in not rich } \\
\text { countries }\end{array}$ & 7.0 & 13.6 & 26.2 \\
\hline \multicolumn{4}{|l|}{$\begin{array}{l}\text { Proportion of } \\
\text { individuals removed } \\
\text { from poverty by Social } \\
\text { Assistance } \\
\text { Native born }\end{array}$} \\
\hline $\begin{array}{l}\text { Both parents born in } \\
\text { Sweden }\end{array}$ & 0.6 & 0.7 & 0.3 \\
\hline $\begin{array}{l}\text { One parent born in } \\
\text { Sweden one parent } \\
\text { foreign born }\end{array}$ & 0.4 & 0.2 & 0.3 \\
\hline $\begin{array}{l}\text { Both parents foreign } \\
\text { born }\end{array}$ & 1.4 & 2.1 & 1.3 \\
\hline Foreign born & & & \\
\hline Born in rich countries & 2.6 & 3.1 & 2.1 \\
\hline $\begin{array}{l}\text { Born in not rich } \\
\text { countries }\end{array}$ & 9.1 & 8.5 & 5.6 \\
\hline
\end{tabular}




\section{Children}

As if no receipt of

social assistance

Native born

Both parents born in

1.4

3.3

6.1

Sweden

One parent born in

3.8

11.4

Sweden one parent

foreign born

Both parents foreign

11.6

18.6

30.5

born

21.3

32.3

Born in rich countries

21.4

30.9

35.9

countries

\section{When considering}

receipt of social

assistance

Native born

Both parents born in

Sweden

One parent born in

9.4

Sweden one parent

foreign born

Both parents foreign

11.3

25.8

born

Foreign born

Born in rich countries

4.7

11.0

24.7

Born in not rich

2.6

12.2

26.1

countries

\section{Proportion of}

individuals removed

from poverty by Social

\section{Assistance}

Native born

Both parents born in

0.1

0.8

0.5

Sweden

One parent born in

1.8

1.3

2.0

Sweden one parent

foreign born

Both parents foreign

7.7

7.3

4.7

born

Foreign born

Born in rich countries

9.2

10.3

18.7

7.6

Born in not rich

18.8

9.8

countries

Note: Estimates based on the Household Income Survey conducted by Statistics Sweden. 
Table 7

Selected academic studies of social assistance receipt among natives and immigrants in Sweden

\begin{tabular}{|c|c|c|c|c|c|}
\hline $\begin{array}{l}\text { STUDY } \\
\text { NUMBER } \\
\text { STUDY }\end{array}$ & $\begin{array}{l}\text { POPULATION } \\
\text { STUDIED }\end{array}$ & $\begin{array}{l}\text { DEFINITIONS } \\
\text { OF } \\
\text { IMMIGRANT }\end{array}$ & $\begin{array}{l}\text { DIMENSION } \\
\text { OF } \\
\text { RECEIPT } \\
\text { STUDIED }\end{array}$ & $\begin{array}{l}\text { DATE AND } \\
\text { PERIOD } \\
\text { OF STUDY }\end{array}$ & $\begin{array}{l}\text { MAIN } \\
\text { RESULTS }\end{array}$ \\
\hline $\begin{array}{l}1 . \\
\text { Gustafsson } \\
(1986)\end{array}$ & $\begin{array}{l}\text { All adult persons } \\
\text { living in Sweden }\end{array}$ & Foreign nationality & $\begin{array}{l}\text { Rates of receipt } \\
\text { observed for a } \\
\text { calendar year }\end{array}$ & $\begin{array}{l}\text { Time series. } \\
\text { Survey data for } \\
1973-77 \text {, } \\
1982 .\end{array}$ & $\begin{array}{l}\text { The number of } \\
\text { immigrants } \\
\text { receiving social } \\
\text { assistance has } \\
\text { increased. } \\
\text { Immigrants have } \\
\text { higher rates of } \\
\text { receipt. }\end{array}$ \\
\hline $\begin{array}{l}2 . \\
\text { Franzén (1997) }\end{array}$ & $\begin{array}{l}\text { All adult persons } \\
\text { living in Sweden }\end{array}$ & $\begin{array}{l}\text { Primary: Foreign } \\
\text { birth }\end{array}$ & $\begin{array}{l}\text { Rates of receipt } \\
\text { observed for one } \\
\text { and several } \\
\text { calendar years }\end{array}$ & $1983-1992$ & $\begin{array}{l}\text { Given age are } \\
\text { immigrant rates } \\
\text { of receipt about } \\
3 \text { times as high. } \\
\text { Rates are high at } \\
\text { entry, but } \\
\text { decrease } \\
\text { thereafter. }\end{array}$ \\
\hline $\begin{array}{l}. \\
\text { Hammarstedt } \\
(2000)\end{array}$ & $\begin{array}{l}\text { All adult persons } \\
\text { living in Sweden }\end{array}$ & Foreign birth & $\begin{array}{l}\text { Probability of } \\
\text { receipt observed } \\
\text { for one calendar } \\
\text { year }\end{array}$ & 1985 and 1990. & $\begin{array}{l}\text { Probabilities of } \\
\text { receipt are high } \\
\text { at entry } \\
\text { particularly } \\
\text { among } \\
\text { immigrants from } \\
\text { not rich } \\
\text { countries but fall } \\
\text { by years since } \\
\text { immigration. }\end{array}$ \\
\hline $\begin{array}{l}4 . \\
\text { Franzén (2001) }\end{array}$ & $\begin{array}{l}\text { All adult persons } \\
\text { living in Sweden }\end{array}$ & Foreign birth & $\begin{array}{l}\text { Probability of } \\
\text { receipt observed } \\
\text { for one calendar } \\
\text { year }\end{array}$ & 1983 and 1995. & $\begin{array}{l}\text { Probabilities of } \\
\text { receipt are high } \\
\text { at entry } \\
\text { particularly } \\
\text { among } \\
\text { immigrants from } \\
\text { not rich } \\
\text { countries but fall } \\
\text { by years since } \\
\text { immigration. }\end{array}$ \\
\hline $\begin{array}{l}5 . \\
\text { Hammarstedt } \\
\text { and Ekberg } \\
\text { (2004) }\end{array}$ & $\begin{array}{l}\text { Second generation } \\
\text { immigrants living } \\
\text { in Sweden and } \\
\text { their statistical } \\
\text { "twins" }\end{array}$ & $\begin{array}{l}\text { Born in Sweden } \\
\text { with both parents } \\
\text { born in the same } \\
\text { region of the word }\end{array}$ & $\begin{array}{l}\text { Probability of } \\
\text { receipt observed } \\
\text { for one calendar } \\
\text { year. }\end{array}$ & 1997 & $\begin{array}{l}\text { Keeping } \\
\text { education and } \\
\text { location constant } \\
\text { a non European } \\
\text { background } \\
\text { increases the } \\
\text { probability of } \\
\text { receipt } \\
\text { profoundly. }\end{array}$ \\
\hline $\begin{array}{l}6 . \\
\text { Hammarstedt } \\
(2009)\end{array}$ & $\begin{array}{l}\text { Persons aged } 20- \\
64 \text { living in } \\
\text { Sweden }\end{array}$ & Foreign birth & $\begin{array}{l}\text { Probability of } \\
\text { receipt observed } \\
\text { for one calendar } \\
\text { year. }\end{array}$ & $\begin{array}{l}1990,1995 \text { and } \\
1999 \text { pooled }\end{array}$ & $\begin{array}{l}\text { Probabilities of } \\
\text { receipt falls after } \\
\text { entry among } \\
\text { immigrants from } \\
\text { not rich }\end{array}$ \\
\hline
\end{tabular}




\begin{tabular}{|c|c|c|c|c|c|}
\hline & & & & & $\begin{array}{l}\text { countries. In } \\
\text { many cases do } \\
\text { more recent } \\
\text { entry cohorts } \\
\text { have higher } \\
\text { probabilities of } \\
\text { receipt than } \\
\text { earlier cohorts. }\end{array}$ \\
\hline $\begin{array}{l}7 . \\
\text { Halleröd (2003) }\end{array}$ & $\begin{array}{l}\text { Persons aged } 20- \\
64 \text { living in } \\
\text { Sweden. }\end{array}$ & $\begin{array}{l}\text { Foreign birth } \\
\text { Foreign nationality }\end{array}$ & $\begin{array}{l}\text { Probability of } \\
\text { receipt observed } \\
\text { for one calendar } \\
\text { year. }\end{array}$ & $\begin{array}{l}1986-87,1996- \\
98\end{array}$ & $\begin{array}{l}\text { Even after } \\
\text { controlling for } \\
\text { unemployment, } \\
\text { household } \\
\text { income (net of } \\
\text { social } \\
\text { assistance), } \\
\text { education and } \\
\text { family type do } \\
\text { foreign } \\
\text { citizenship } \\
\text { positively affect } \\
\text { probability of } \\
\text { receipt. }\end{array}$ \\
\hline $\begin{array}{l}8 . \\
\text { Hansen and } \\
\text { Lofstrom } \\
\text { (2003) }\end{array}$ & $\begin{array}{l}\text { Persons aged } 18- \\
65 \text { living in } \\
\text { Sweden } 1990 .\end{array}$ & Foreign birth & $\begin{array}{l}\text { Probability of } \\
\text { receipt observed } \\
\text { for one calendar } \\
\text { year. }\end{array}$ & $1990-1996$ & $\begin{array}{l}\text { Probabilities of } \\
\text { receipt fall with } \\
\text { years since } \\
\text { immigration } \\
\text { particularly for } \\
\text { migrants from } \\
\text { not rich } \\
\text { countries (here } \\
\text { called refugee } \\
\text { countries). } \\
\text { Immigrants are } \\
\text { not predicted to } \\
\text { reach parity with } \\
\text { natives during } \\
\text { two decades } \\
\text { after } \\
\text { immigration. } \\
\end{array}$ \\
\hline $\begin{array}{l}9 . \\
\text { Hansen and } \\
\text { Lofstrom } \\
\text { (2009) }\end{array}$ & $\begin{array}{l}\text { Males aged } 18-65 \\
\text { living in Sweden } \\
1990 .\end{array}$ & Foreign birth & $\begin{array}{l}\text { Transition into } \\
\text { and out of social } \\
\text { assistance, } \\
\text { unemployment } \\
\text { and employment. }\end{array}$ & $1990-1996$ & $\begin{array}{l}\text { Particularly } \\
\text { immigrants from } \\
\text { not rich } \\
\text { countries display } \\
\text { a greater degree } \\
\text { of "structural" } \\
\text { state dependency } \\
\text { than natives. The } \\
\text { high social } \\
\text { assistance rate } \\
\text { among } \\
\text { immigrants from } \\
\text { not rich } \\
\text { countries may be } \\
\text { due to the } \\
\text { existence of a } \\
\text { "welfare trap", } \\
\text { while } \\
\text { participation } \\
\text { among others is } \\
\text { largely due to }\end{array}$ \\
\hline
\end{tabular}




\begin{tabular}{|c|c|c|c|c|c|}
\hline & & & & & $\begin{array}{l}\text { permanent } \\
\text { unobserved } \\
\text { characteristics. }\end{array}$ \\
\hline $\begin{array}{l}10 . \\
\text { Gustafsson } \\
\text { (1998) }\end{array}$ & $\begin{array}{l}\text { Males born } 1932 \text { to } \\
1979 \text { not receiving } \\
\text { social assistance } \\
\text { but entering } \\
\text { unemployment } \\
\text { during } 1993 \text { and } \\
1994 \text { in the city of } \\
\text { Gothenburg. }\end{array}$ & Foreign citizenship & $\begin{array}{l}\text { Entry into social } \\
\text { assistance receipt } \\
\text { during the first } \\
18 \text { months after } \\
\text { entering } \\
\text { unemployment }\end{array}$ & $\begin{array}{l}1993-94 \text { and } \\
\text { following } 18 \\
\text { months }\end{array}$ & $\begin{array}{l}\text { Probability of } \\
\text { receipt is high } \\
\text { for when } \\
\text { unemployment } \\
\text { has a long } \\
\text { duration and the } \\
\text { unemployed is } \\
\text { not receiving } \\
\text { unemployment } \\
\text { benefits and is } \\
\text { young. }\end{array}$ \\
\hline $\begin{array}{l}11 . \\
\text { Gustafsson et } \\
\text { al. (2002) }\end{array}$ & $\begin{array}{l}\text { Households aged } \\
\text { under } 64 \text { entering } \\
\text { social assistance in } \\
\text { the city of } \\
\text { Gothenburg April } \\
1991 \text { to March } \\
1992 \text { Helsingborg } \\
1989 \text { and Barcelona } \\
\text { (ES), Bremen (D), } \\
\text { Lisbon (P), Milan } \\
\text { (IT), Turin (IT) and } \\
\text { Vitoria (ES). }\end{array}$ & Foreign citizenship & $\begin{array}{l}\text { Duration of } \\
\text { episodes during } \\
\text { the first } 42 \\
\text { months }\end{array}$ & $\begin{array}{l}1991-1995 \\
\text { (Gothenburg) } \\
1989-1993 \\
\text { (Helsingborg) }\end{array}$ & $\begin{array}{l}\text { Only in the } \\
\text { Swedish and the } \\
\text { German cities do } \\
\text { immigrants have } \\
\text { longer periods of } \\
\text { first time receipt } \\
\text { than natives. } \\
\text { Controlling for } \\
\text { some } \\
\text { demographic } \\
\text { factors do a } \\
\text { foreign } \\
\text { background } \\
\text { prolong periods } \\
\text { of receipt in } \\
\text { Swedish cities, } \\
\text { but reduce } \\
\text { periods in } \\
\text { Lisbon, Milan } \\
\text { and Turin. }\end{array}$ \\
\hline $\begin{array}{l}12 . \\
\text { Bergmark and } \\
\text { Bäckman } \\
(2004)\end{array}$ & Sweden as a whole & Foreign born & $\begin{array}{l}\text { Probability of } \\
\text { leaving long term } \\
\text { receipt (defined } \\
\text { as receipt during } \\
\text { at least } 10 \\
\text { months during a } \\
\text { calendar year), } \\
\text { re-entry into long } \\
\text { term receipt }\end{array}$ & 1992 - 1999 & $\begin{array}{l}\text { Variation over } \\
\text { time is much a } \\
\text { function of the } \\
\text { labour market. } \\
\text { Probabilities of } \\
\text { leaving and } \\
\text { entering are } \\
\text { higher among } \\
\text { recent arrived } \\
\text { immigrants. }\end{array}$ \\
\hline $\begin{array}{l}13 . \\
\text { Mood (2009) }\end{array}$ & $\begin{array}{l}\text { Adults living in the } \\
\text { city of Stockholm }\end{array}$ & Foreign born & $\begin{array}{l}\text { Long term receipt } \\
\text { (defined as } \\
\text { receipt during at } \\
\text { least } 10 \text { months } \\
\text { during a calendar } \\
\text { year) }\end{array}$ & 1990,2003 & $\begin{array}{l}\text { Nearly half of } \\
\text { the increase in } \\
\text { the proportion } \\
\text { long term } \\
\text { recipients can be } \\
\text { attributed to } \\
\text { increased } \\
\text { representation of } \\
\text { immigrants in } \\
\text { the populations, } \\
\text { and most of the } \\
\text { other half to } \\
\text { increased } \\
\text { dependency } \\
\text { among } \\
\text { immigrants. The }\end{array}$ \\
\hline
\end{tabular}




\begin{tabular}{|l|l|l|l|l|l|}
\hline \hline & & & & $\begin{array}{l}\text { contribution of } \\
\text { natives to the } \\
\text { increase in long } \\
\text { term dependency } \\
\text { is marginal. }\end{array}$ \\
\hline
\end{tabular}


Table 8

Probabilities of receiving social assistance in 1995 for a 40 year old single women having various characteristics. Percent

\begin{tabular}{|c|c|c|c|}
\hline \multirow[t]{2}{*}{$\begin{array}{l}\text { Country of birth } \\
\text { and number of } \\
\text { years since } \\
\text { immigration }\end{array}$} & Level of & & \\
\hline & Primary & Secondary & University level \\
\hline Born in Sweden & 8 & 5 & 1 \\
\hline $\begin{array}{l}\text { Born in a Nordic } \\
\text { country }\end{array}$ & & & \\
\hline - 5 years & 24 & 21 & 13 \\
\hline $6-15$ years & 9 & 6 & 4 \\
\hline $16-27$ years & 3 & 3 & 1 \\
\hline \multicolumn{4}{|l|}{$\begin{array}{l}\text { Born in a country in } \\
\text { western Europe and } \\
\text { Northern America }\end{array}$} \\
\hline - 5 years & 14 & 12 & 7 \\
\hline $6-15$ years & 4 & 3 & 2 \\
\hline $16-27$ years & 2 & 1 & 1 \\
\hline \multicolumn{4}{|l|}{ Born in a Eastern } \\
\hline \multicolumn{4}{|l|}{ Europe } \\
\hline - 5 years & 32 & 38 & 33 \\
\hline $6-15$ years & 8 & 6 & 5 \\
\hline $16-27$ years & 3 & 3 & 3 \\
\hline \multicolumn{4}{|l|}{ Born in a Southern } \\
\hline \multicolumn{4}{|l|}{ Europe } \\
\hline-5 years & 68 & 73 & 69 \\
\hline $6-15$ years & 24 & 17 & 13 \\
\hline $16-27$ years & 10 & 9 & 5 \\
\hline \multicolumn{4}{|l|}{ Born in a Middle } \\
\hline \multicolumn{4}{|l|}{ East } \\
\hline - 5 years & 67 & 72 & 68 \\
\hline $6-15$ years & 29 & 23 & 17 \\
\hline $16-27$ years & 13 & 11 & 12 \\
\hline \multicolumn{4}{|c|}{$\begin{array}{l}\text { Born in other not rich } \\
\text { countries }\end{array}$} \\
\hline - 5 years & 55 & 62 & 57 \\
\hline $6-15$ years & 20 & 15 & 12 \\
\hline $16-27$ years & 9 & 7 & 8 \\
\hline
\end{tabular}

Source: Franzén (2001)

Note: Calculation based on a estimated probability model. It is assumed that the person is living in metropolitan area where the unemployment rate is 8 percent. 


\section{Table 9}

Probabilities of receiving entering social assistance receipt within 18 months after entering unemployment for persons of different characteristics and length of unemployment. Percent

\begin{tabular}{|c|c|c|c|}
\hline Individual & Leng & lent (mon & \\
\hline $\begin{array}{l}\text { Aged } 25-34 \text { years } \\
\text { having compulsory } \\
\text { schooling and }\end{array}$ & -3.0 & $3.1-6.0$ & $6.1-$ \\
\hline $\begin{array}{l}\text { - Swedish citizen and } \\
\text { entitled to } \\
\text { Unemployment } \\
\text { Benefit }\end{array}$ & 7.4 & 10.0 & 17.9 \\
\hline $\begin{array}{l}\text { Swedish citizen and } \\
\text { not entitled to } \\
\text { Unemployment } \\
\text { Benefit }\end{array}$ & 19.6 & 31.2 & 52.1 \\
\hline $\begin{array}{l}\text { - Citizen in East } \\
\text { European country } \\
\text { and entitled to } \\
\text { Unemployment } \\
\text { Benefit }\end{array}$ & 13.3 & 17.7 & 29.7 \\
\hline $\begin{array}{l}\text { Citizen in East } \\
\text { European country } \\
\text { and entitled to } \\
\text { Unemployment } \\
\text { Benefit } \\
\text { Aged at lest } 55 \text { years } \\
\text { and having university } \\
\text { education. }\end{array}$ & 32.0 & 46.8 & 67.8 \\
\hline $\begin{array}{l}\text { - Swedish citizen and } \\
\text { entitled to } \\
\text { Unemployment } \\
\text { Benefit }\end{array}$ & 1.0 & 1.4 & 2.8 \\
\hline $\begin{array}{l}\text { Swedish citizen and } \\
\text { not entitled to } \\
\text { Unemployment } \\
\text { Benefit }\end{array}$ & 3.1 & 5.6 & 12.4 \\
\hline
\end{tabular}

Source: Gustafsson (1998) 
Table 10

Median duration of first cash episode of social assistance receipt by nationality in eight European countries. Months

\begin{tabular}{|c|c|c|c|c|}
\hline Country & City & Non-nationals & Nationals & $\begin{array}{l}\text { Indicator of } \\
\text { statistical } \\
\text { significancy } \\
\text { between non } \\
\text { national and } \\
\text { nationals }\end{array}$ \\
\hline Spain & Barcelona & 35.0 & 27.0 & \\
\hline Germany & Bremen & 7.4 & 4.8 & $* * *$ \\
\hline Sweden & Gothenburg & 7.6 & 2.7 & $* * *$ \\
\hline Sweden & Helsingborg & 10.2 & 3.7 & $* * *$ \\
\hline Portugal & Lisbon & 23.5 & 34.2 & $* *$ \\
\hline Italy & Milan & 3.9 & 5.0 & $*$ \\
\hline Italy & Turin & 4.0 & 6.3 & $* *$ \\
\hline Spain & Vitoria & 14.5 & 11.5 & \\
\hline
\end{tabular}

Source: Gustafsson et al. (2002 p 213).

Note: *** indicates stat sign at least 1 percent level, ** at least 5 percent level, but not at 1 percent level, * at 10 percent, but not 5 percent level. 